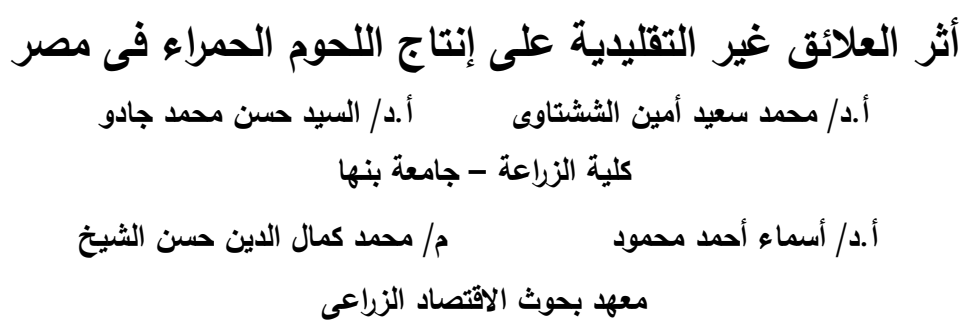

Corresponding author: mm_elsheikh2005@yahoo.com

مقدمة:

تعد مشكلة نقص البروتين الحيواني من أهم المشكلات التى نعترض تحسين المستوى الغذائي فى الدول النامية، وذلك للزيادة السكانية

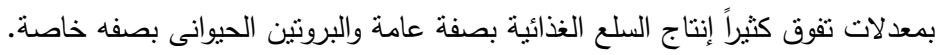

كما يعتبر توفير الغذاء وتحقيق الأمن الغذائى من القضايا الهامة التى تحظى بأهتمام عالمى كبير يتزايد يوماً بعد آخر نتيجة للعديد من

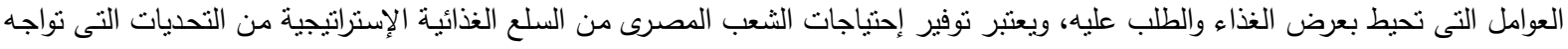

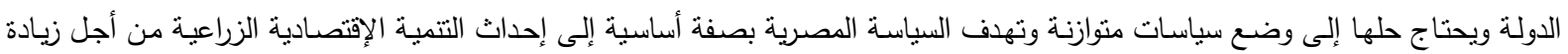

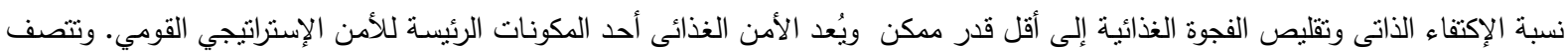

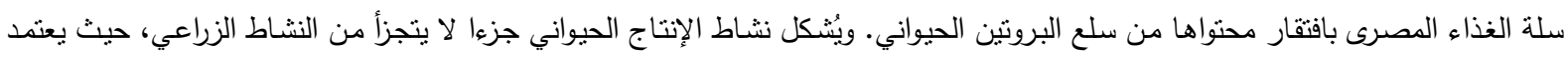

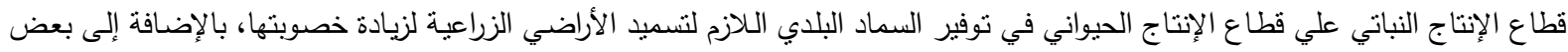

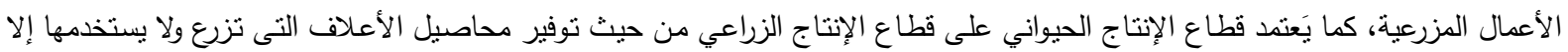

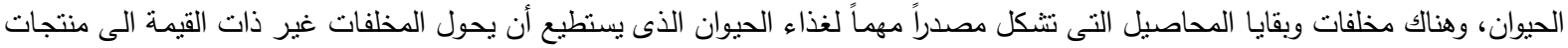
غذائية ــمن لحم ولبن_ذات قيمة اقتصادية عالية.

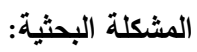

تتمنل مشكلة البحث في عجز الطاقة الإنتاجية من الموارد العلفية للحيوانات المزرعية فى الزراعة المصرية عن تغطية الإحتياجات الحيوانية لتلاك الموارد، ويقدر هذا العز فى الغذاء للحيوانات المجترة بحوالى 3.5 مليون طن من المواد الغذائية المهضومة أى مايعادل 6 مليون طن أعلاف مصنعة وتمثل الأعلاف الجانب الأكبر فى تكلفة الإنتاج الحيوانى في مصر على تلبية احتياجات الطلب المتزايد عليه نتيجة زيادة السكان وزيادة مستوى المعيشة، وتزداد حدة هذه المشكلة نظرا لما تعانيه مصر من نقص في مواد العلف الحيواني بالإضافة إلى وجود إهدار في النواتج

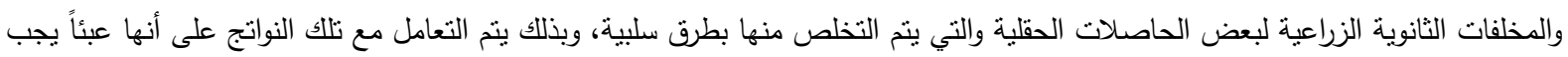
التخلص منه وليست مورداً اقتصادياً وبيئياً هاماً، لذلك لابد من الاستفادة الكاملة منها عن طريق الاستغلال والتنوير الأمتل في صناعة الأعلاف

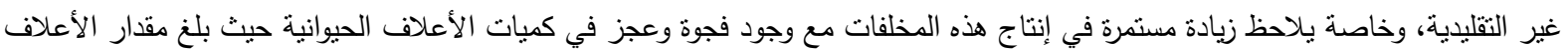
الحيوانية غير التقليدة الدنتجة من أعادة تدوير المخلفات الزراعية النباتية نحو 23 ألف طن تثتل نحو 0,19\% من أجمالى كية المخلفات

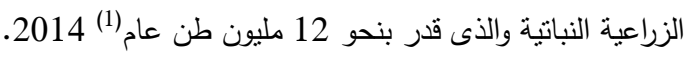

أهداف البحث : تهدف الدراسة إلى دراسة الوضع الإنتاجي الراهن لمانية التسمين في جمهورية مصر العربية بصفة عامة وكنلك دراسة الوضع الإنتاجى

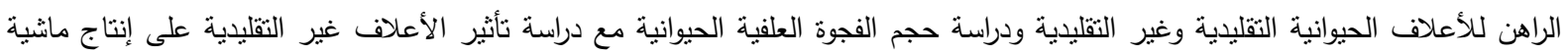
التسمين وذللك من خلال تحقيق الأهداف الفرعية التالية:

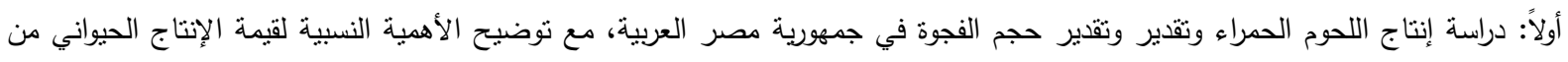
اجمالى قيمة الإنتاج الزراعي المصري.

(1) وزارة الزراعة وأسنصلاح الأراضى ، قطاع الثئون الإقتصادية ، "تشرات الإقتصاد الزراعى" ، أعداد متفرقة. 
ثنانياً: دراسة إنتاج أعلاف المانية في مصر بأنواعها المختلفة الخضراء، والجافة، والمركزة، التقليدية وغير التقليدية وإبراز أهميتها النسبية، وتقدير الفجوة العلفية الحيوانية في قطاع الزراعة. ثالثاً: دراسة موسمية الأعلاف غير التقليدية على إنتاج ماثية التسمين في مصر من عينة الدراسة.

الطريقة البحثية ومصادر البيانات:

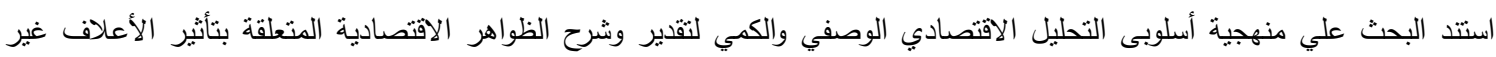

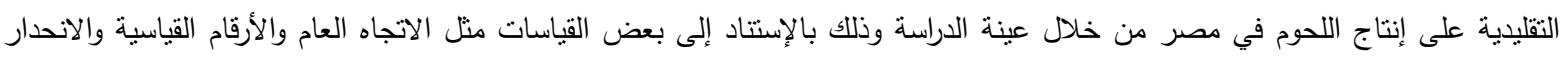

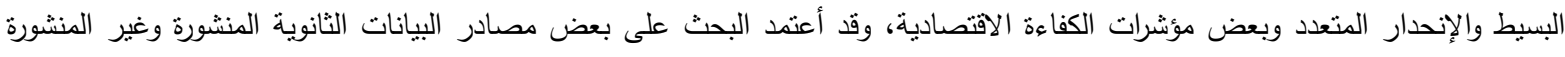

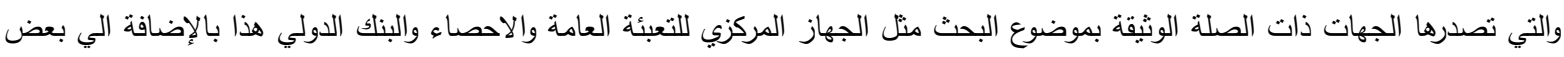

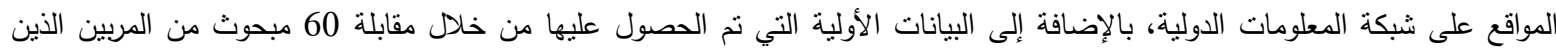

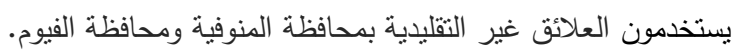

مناقثة النتائج : الطاقة الإنتاجية للحوم الحمراء فى مصر - الميزان الغذائى ودرجة الاكتفاء الذاتي من اللحوم الحمراء:

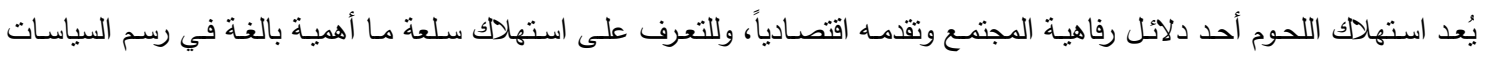

الإنتاجية والسعرية والتسويقية والتصديرية والاستيرادية لهذه السلعة.

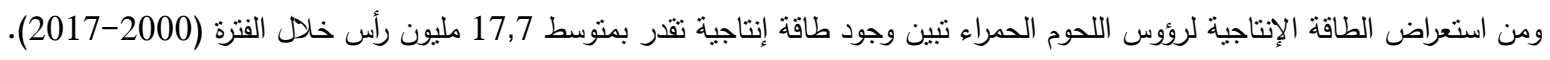

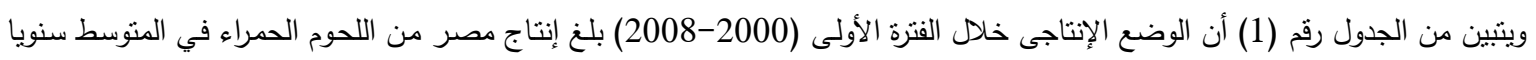

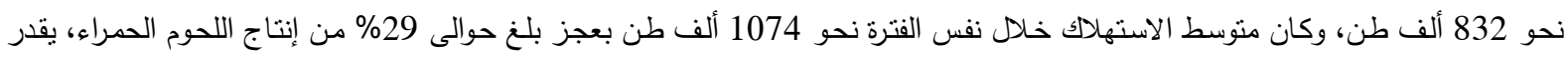

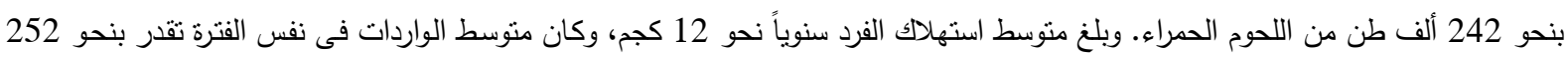
ألف طن. ويتضح من دراسة الوضع الإنتاجى خلال الفترة الثانية (2009-2017) حيث بلغ إنتاج مصر من اللحوم الحمراء فى الكنوسط سنوياً

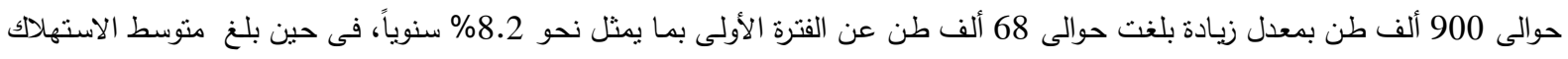

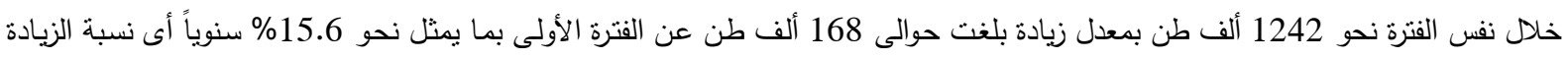

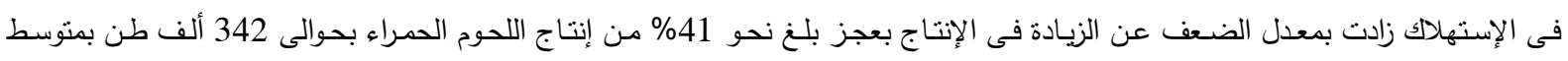

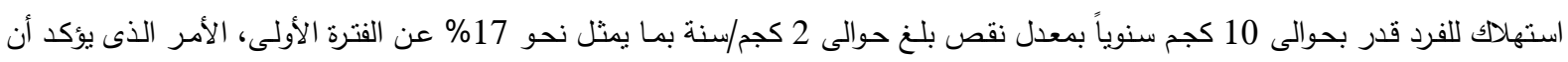

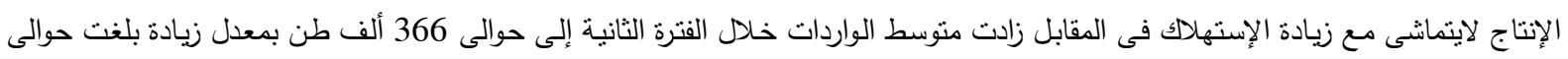

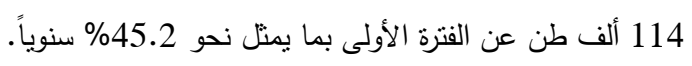

\section{تطور إنتاج اللحوم الحمراء في مصر}

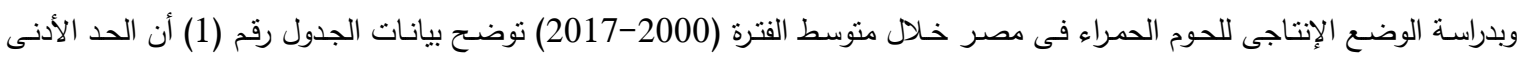

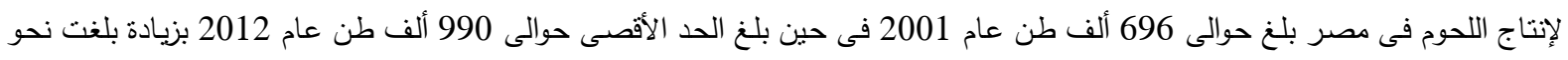

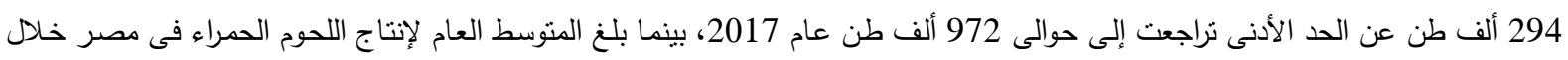
الفترة (2000-2017) حوالى 904 ألف طن سنوياً.

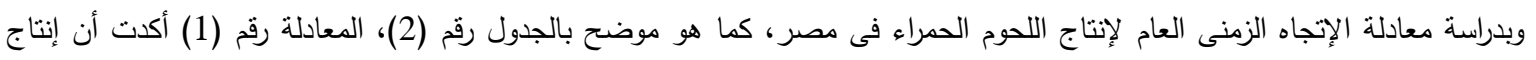

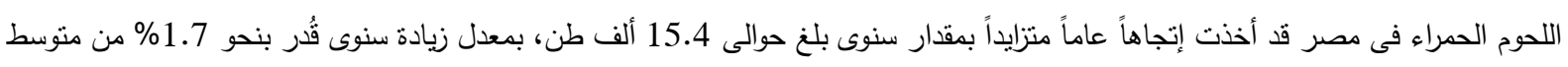

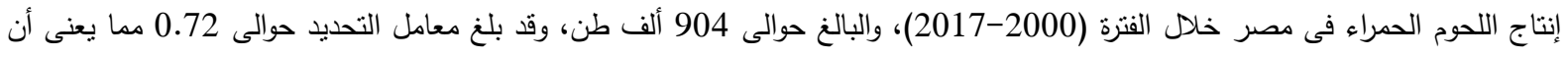

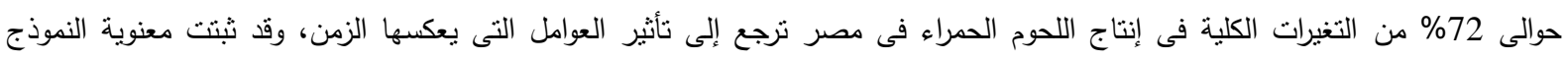
المقدر. 
تطور إستهلاك اللحوم الحمراء فى مصر

بدراسة الوضع الإستهلاكى للحوم الحمراء فى مصر خلال متوسط الفترة (2000-2017) تثير بيانات الجدول رقم (1) أن الحد الأدنى

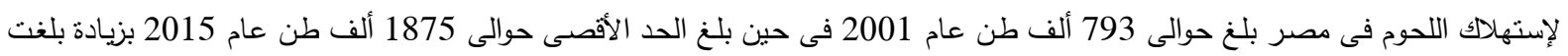

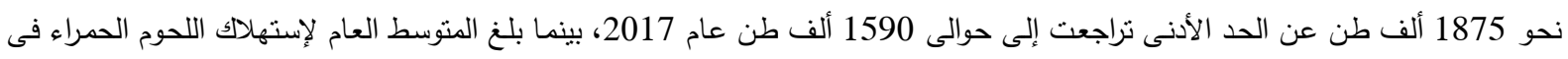
مصر خلال الفنزة (2000-2017) حوالى 1252 ألف طن سنوياً.

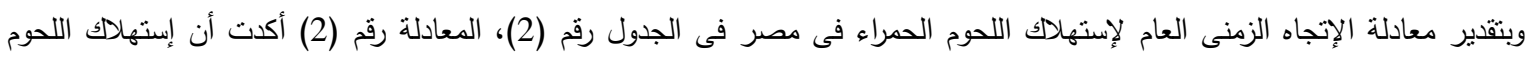

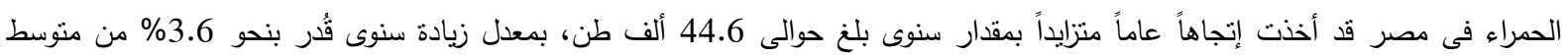

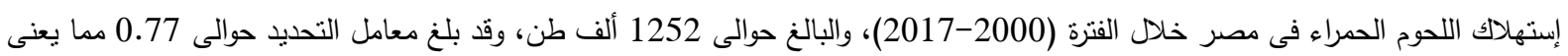

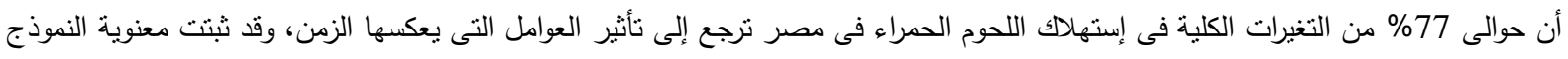
المقدر .

جدول رقم(1) تطور الإنتاج والاستهلاك والفجوة والاكتفاء الذاتي والواردات ومتوسط نصيب الفرد من اللحوم الحمراء خلال الفترة (2000-2017)

\begin{tabular}{|c|c|c|c|c|c|c|}
\hline كجيب الفرد & الواردات بالألف & 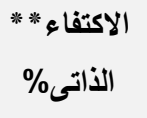 & بالألف طن & بالألف طن & بالألف طن & السنوات البيان \\
\hline 11 & 227 & 75.5 & 229- & 934 & 705 & 2000 \\
\hline 9,1 & 100 & 87.8 & 97- & 793 & 696 & 2001 \\
\hline 10,8 & 139 & 85.5 & $139-$ & 960 & 821 & 2002 \\
\hline 11,2 & 179 & 82.4 & 179- & 1019 & 840 & 2003 \\
\hline 10,4 & 152 & 85.2 & $142-$ & 960 & 818 & 2004 \\
\hline 11,1 & 272 & 75.5 & $278-$ & 1133 & 855 & 2005 \\
\hline 12,7 & 434 & 67.0 & $433^{-}$ & 1312 & 879 & 2006 \\
\hline 13 & 456 & 66.4 & $465^{-}$ & 1382 & 917 & 2007 \\
\hline 10,9 & 307 & 81.7 & $215-$ & 1176 & 961 & 2008 \\
\hline 12 & 252 & 78.2 & $242-$ & 1074 & 832 & متوسط الفترة \\
\hline 10,9 & 215 & 82.0 & $215^{-}$ & 1196 & 981 & 2009 \\
\hline 9,8 & 195 & 77.7 & $285^{-}$ & 1277 & 992 & 2010 \\
\hline 9,4 & 212 & 76.4 & $306^{-}$ & 1294 & 988 & 2011 \\
\hline 9,2 & 309 & 80.6 & $239-$ & 1229 & 990 & 2012 \\
\hline 9.7 & 308 & 69.0 & $433^{-}$ & 1397 & 964 & 2013 \\
\hline 10.1 & 348 & 63.7 & $541-$ & 1492 & 951 & 2014 \\
\hline 11.4 & 781 & 52.0 & $900^{-}$ & 1875 & 975 & 2015 \\
\hline 9.2 & 427 & 64.1 & $543-$ & 1511 & 968 & 2016 \\
\hline 8.9 & 503 & 61.1 & $618^{-}$ & 1590 & 972 & 2017 \\
\hline 10 & 366 & 73.7 & $342-$ & 1242 & 900 & متوسط الفترة \\
\hline 9.9 & 309 & 73.4 & $348-$ & 1252 & 904 & المتوسط العام \\
\hline
\end{tabular}


جدول (2) معادلات الاتجاه الزمنى العام لنطور كل من إنتاج وإستهلاك والفجوة والإكتفاء الذانى والواردات ونصيب الفرد من اللحوم الحمراء فى مصر خلال الفترة (2000-2017).

\begin{tabular}{|c|c|c|c|c|c|}
\hline $\begin{array}{c}\text { معدل التغير } \\
\text { \% }\end{array}$ & ف المحسوية & معامل التحديد & قيمة & معادلات الاتجاه الزمنى العام & البيان \\
\hline 1.7 & 44.69 & 0,72 & $* *(6,68)$ & ص^ه = 758+ 15.4 سه & 1- تطور إنتاج اللحوم \\
\hline 3.6 & 57.9 & 0,77 & $* *(7,61)$ & ص^^= 828+64.6 سه & 2- تطور إستهلاك اللحوم \\
\hline 8.4 & 21 & 0,54 & $* *(4,58)$ & ص^ه =070 70.3س & 3- تطور الفجوة من اللحوم \\
\hline 1,8 & 15,4 & 0,46 & $* *(3,93-)$ & صه =87- 1. 1. مه. & 4- تظور نسبة الإكتقاء \\
\hline 6,5 & 11,6 & 0,38 & $* *(3,4)$ & ص^^ =118+ 20س^ه & 5- تطور الواردات من \\
\hline 6,9 & 5,9 & 0,22 & $*(2,43-)$ & ص^ه =113- 4.7 س^ه & 6- تطور نصيب الفرد من \\
\hline
\end{tabular}

المصدر: قدرت من بيانات الجدول رقم (1).

\section{تطور الفجوة من اللحوم الحمراء فى مصر}

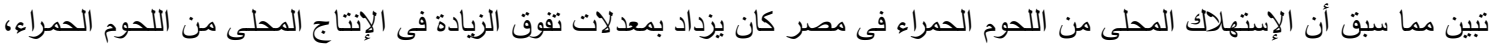

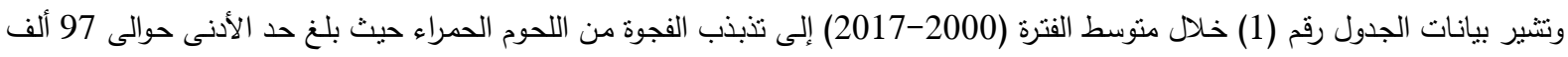

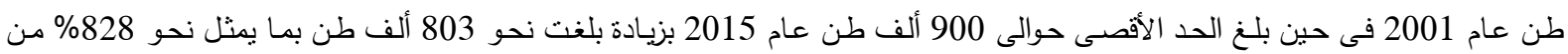

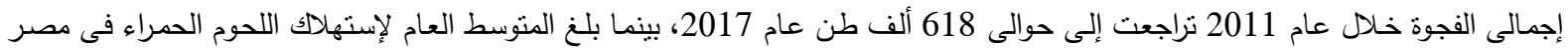
خلا الفترة (2000-2017) حوالى 1252 ألف طن سنوياً، ويعزى ذلك لزيادة السكان بنسب أعلى من الزيادة فى الإنتاج، وبلغ المنوسط العام

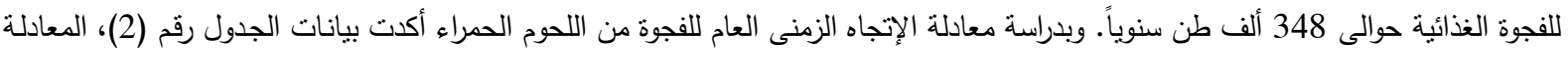

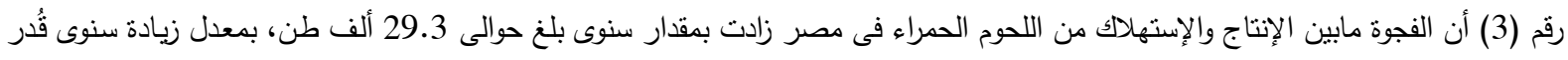
بنحو 8.4\% من متوسط إنتاج اللحوم الحمراء فى مصر خلال الفترة (2000-2017)، والبالغ حوالى (-348) ألف طن، وقد بلغ معامل التحديد

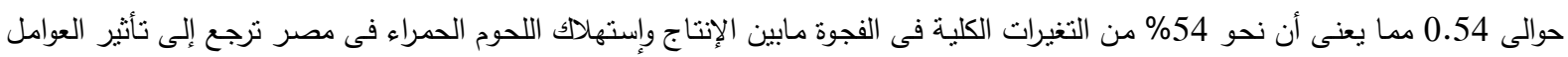
التى يعكسا الزمن، وقد ثتبت معنوية النموذج المقدر .

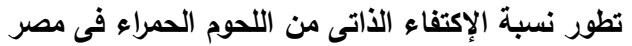

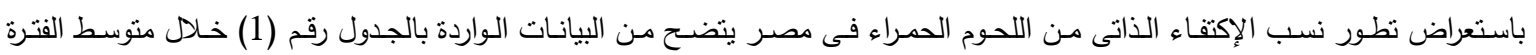
(2000-2017) أن معدل الإكتفاء الذانى من اللحوم الحمراء قد تذبذب حيث كان الحد الأقصى له يمثل نحو 87.8 87.

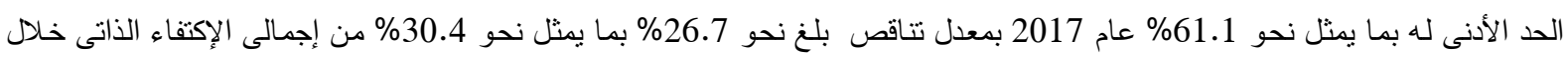

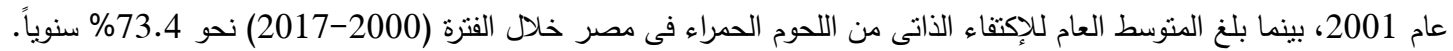

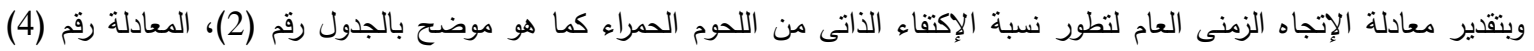

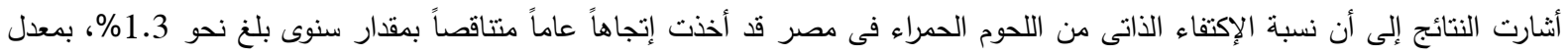
نقص سنوى قُر بنحو 1.8\% من منوسط نسبة الإكتفاء الذاتى من اللحوم الحمراء فى مصر خلال الفترة (2000-2017)، والبالغ نحو

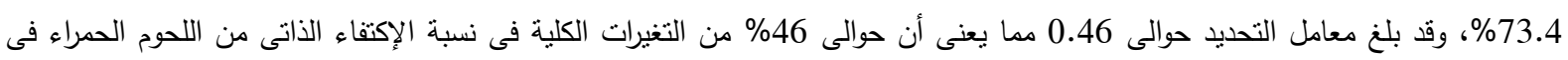

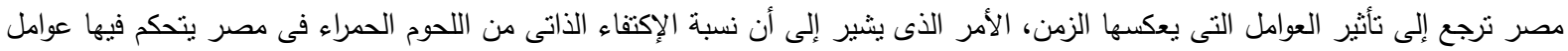




\section{الوضع الإنتاجى الراهن لأعلاف الماشية فى مصر

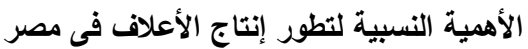

وتعتبر أهم الأعلاف المصرية هى الأعلاف الخضراء، والتى تضم البرسيم المستديم، وبرسيم التحريش، والبرسيم الحجازى، بالأضافة إلى محاصيل العلف الأخضر كعلف الفيل، والدراوة والذرة السكرية والدنيية ولوبيا العلف والدخن، كما تتمتل فى الأعلاف الخشنة، والتى تضم تبن الفول، وتبن التبن

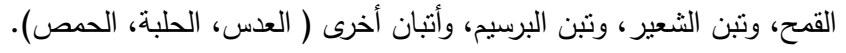

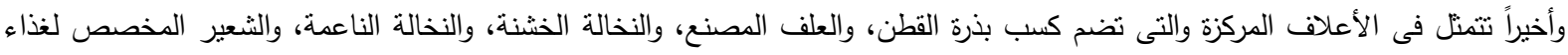

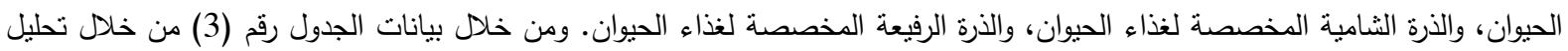

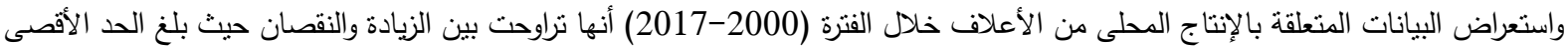

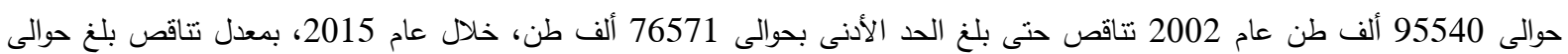

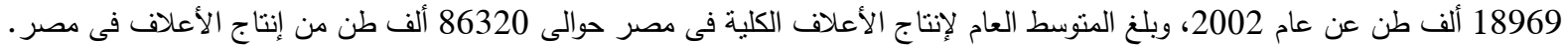

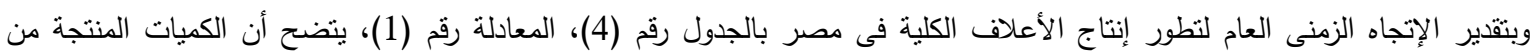
الأعلاف خلال الفتزة (2000-2017)، قد أخذت إنجاهاً عاماً متتاقصاً سنوياً بلغ نحو 906 ألف طن سنوياً، وقد بلغ معامل النحديد حوالى الثى

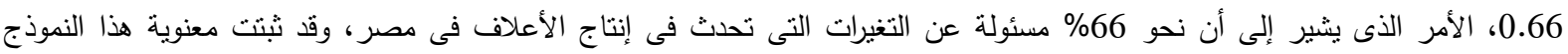
إحصائياً، وبحساب معدل التغير السنوى لنظور كمية الأعلاف الكلية يتضح تناقص كمية إنتاج الأعلاف الكلية بمعدل سنوى معنوى إحصائياً يقدر بنحو 1,05\% من منوسط كمية الأعلاف الكلية الذى قدر بنحو 86320 ألف طن وذلك خلال الفترة (2000-2017).

\begin{tabular}{|c|c|c|c|c|c|c|c|}
\hline \multicolumn{3}{|c|}{ خلال الفترة (2000-2017) (الكمية: بالألف طن) } & \multicolumn{5}{|c|}{ جدول رقم 3 ـ الأهمية النسبية لنطور إنتاج الأنواع المختلفة من الأعلاف فى مصر } \\
\hline \multirow{2}{*}{ إجمالى إنتاج } & \multicolumn{2}{|c|}{ كمية الأعلاف المركزة" *" } & \multicolumn{2}{|c|}{ كمية الأعلاف الخشنة" } & \multicolumn{2}{|c|}{ كمبة الأعلاف الخضراء" } & \multirow{2}{*}{ البيان } \\
\hline & $\%$ & الإنتاج & $\%$ & الإنتاج & $\%$ & 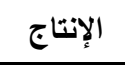 & \\
\hline 87842 & 9.1 & 8023 & 18.9 & 16586 & 72.0 & 63233 & 2000 \\
\hline 90109 & 8.6 & 7755 & 17.5 & 15773 & 73.9 & 66581 & 2001 \\
\hline 95540 & 8.2 & 7854 & 17.1 & 16350 & 74.7 & 71336 & 2002 \\
\hline 95254 & 7.4 & 7022 & 17.3 & 16470 & 75.3 & 71762 & 2003 \\
\hline 91238 & 6.1 & 5526 & 18.4 & 16785 & 75.5 & 68927 & 2004 \\
\hline 87834 & 9.5 & 8359 & 20.5 & 18022 & 70.0 & 61453 & 2005 \\
\hline 86799 & 8.3 & 7181 & 21.0 & 18230 & 70.7 & 61388 & 2006 \\
\hline 92547 & 8.5 & 7824 & 19.2 & 17754 & 72.4 & 66969 & 2007 \\
\hline 88134 & 9.2 & 8131 & 21.1 & 18559 & 69.7 & 61444 & 2008 \\
\hline 82860 & 9.8 & 8097 & 22.0 & 18191 & 68.3 & 56572 & 2009 \\
\hline 88322 & 9.9 & 8770 & 19.0 & 16776 & 71.1 & 62776 & 2010 \\
\hline 89268 & 11.1 & 9927 & 19.7 & 17599 & 69.2 & 61742 & 2011 \\
\hline 84491 & 11.3 & 9550 & 20.4 & 17261 & 68.3 & 57680 & 2012 \\
\hline 81751 & 12.2 & 9998 & 22.5 & 18423 & 65.2 & 53330 & 2013 \\
\hline 77141 & 11.2 & 8630 & 23.2 & 17885 & 65.6 & 50626 & 2014 \\
\hline 76571 & 14.8 & 11309 & 23.2 & 17777 & 62.0 & 47485 & 2015 \\
\hline 79852 & 12.5 & 9970 & 24.9 & 19883 & 62.6 & 49999 & 2016 \\
\hline 78212 & 13.6 & 10640 & 24.1 & 18830 & 62.3 & 48742 & 2017 \\
\hline 86320 & 9.84 & 8587 & 20.42 & 17620 & 69.24 & 60114 & المتوسط \\
\hline
\end{tabular}

المصدر : جمعت وحسبت من بيانات وزارة الزراعة واستصلاح الأراضى، قطاع الثئُن الاقتصادية، الإدارة العامة للموارد الزراعية، نشرات تقليرات الدخل الزراعى، 
أولاً: تطور إنتاج الأعلاف الخضراء فى مصر

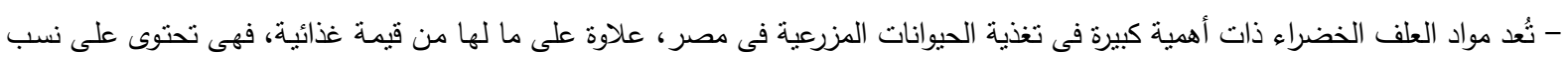

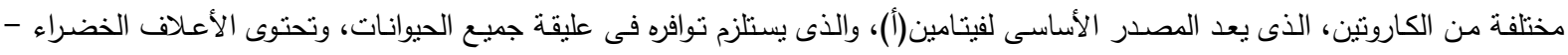

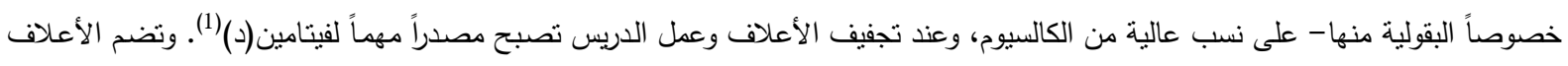

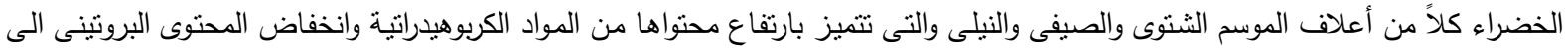

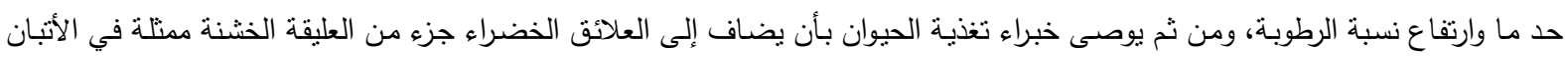

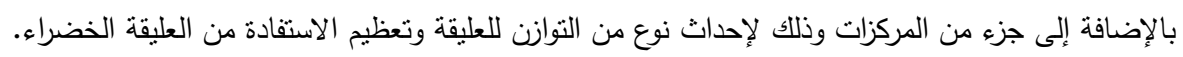

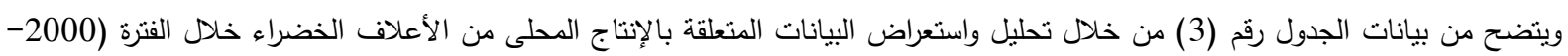

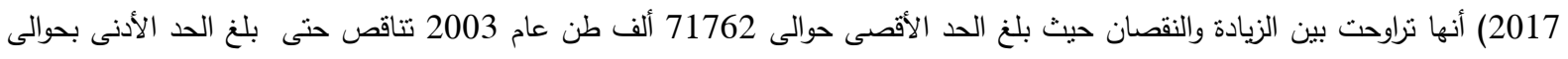

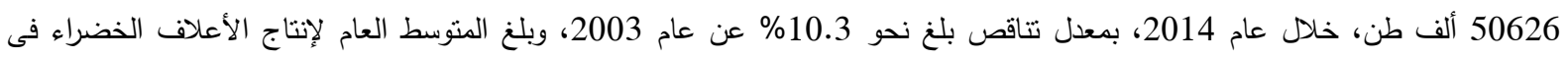

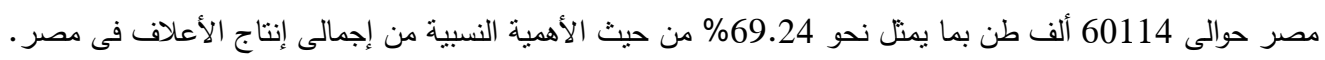

جدول (4) معادلات الاتجاه الزمنى العام لتطور كل من كمية الأعلاف الخضراء والخشنة والمركزة فى مصر خلال الفترة (2000-2017).

\begin{tabular}{|c|c|c|c|c|c|}
\hline $\begin{array}{c}\text { معدل } \\
\text { \% } \\
\text { \% } \\
\end{array}$ & قالمحسوية & قيمة (T) & معامل التحديد & معادلات الاتجاه الزمنى العام & البيان \\
\hline 1.05 & 33,76 & $* *(5,81-)$ & 0,66 & = = 94926- 906 سهد & 1- تطور كمية الأعلاف الكلية \\
\hline 2.09 & 53,38 & $* *(7,30)$ & 0,76 & ص ه. = 72075- 1259 سه & 2- تطور كمية الأعلاف الخضراء \\
\hline 0,8 & 18,50 & $* *(4,30)$ & 0,51 & ص ^ر= 16277+ 141 سهـ & 3- تطور كمية الأعلاف الخثنة \\
\hline 2,5 & 26,9 & $* *(5,19)$ & 0,60 & صی^, =6573 + 212س ^ه & 4- تطور كمية الأعلاف المركزة \\
\hline
\end{tabular}

المصدر: حسبت من بيانات الجدول رقم (3) بالدراسة.

وبتقدير الإتجاه الزمنى العام لتطور إنتاج الأعلاف الخضراء فى مصر بالجدول رقم (4)، المعادلة رقم (2)، يتضح أن الكيات المنتجة من

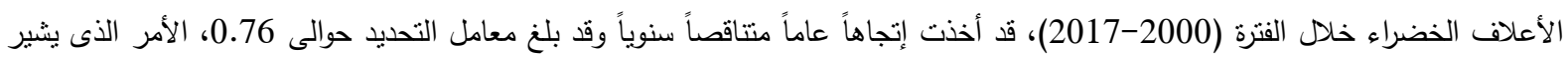

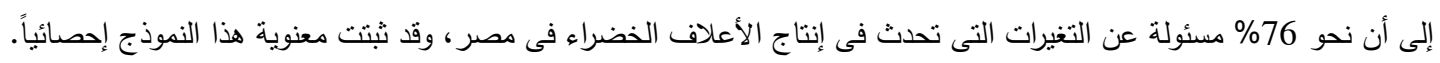

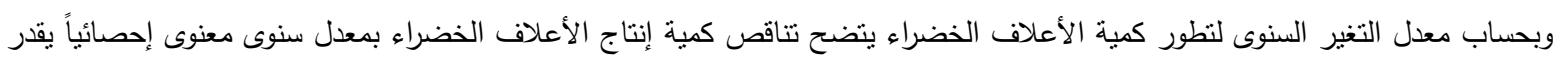
بنحو 2,09\% من متوسط كمية الأعلاف الخضراء الذى قدر بنحو 60114 ألف طن وذللك خلاء الفترة (2000-2017).

ثانياً: تطور إنتاج الأعلاف الخثنة فى مصر

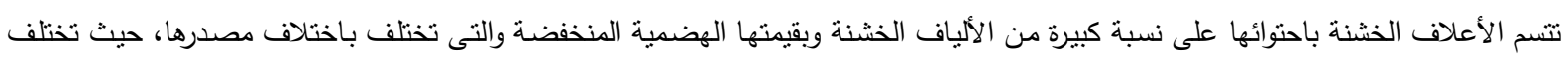

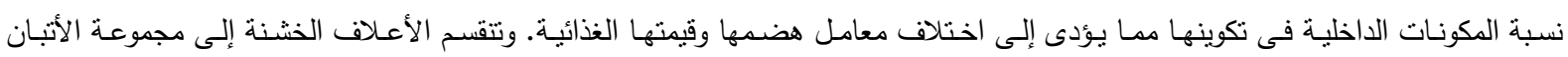

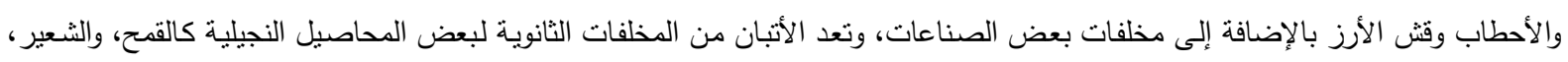

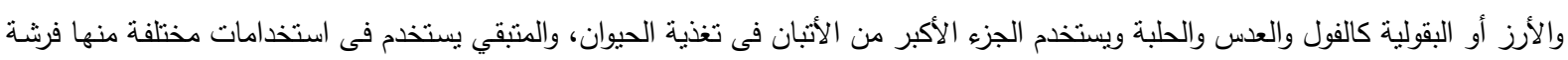

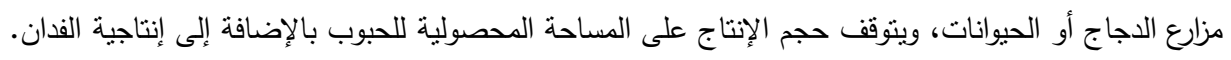

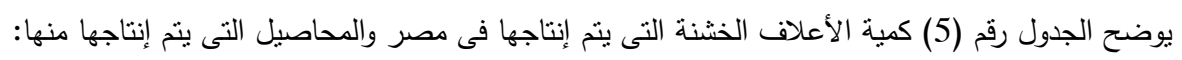

(1) رضـا سـلامة (دكتور )، وآخرون، الأسسس العلميـة فحى تغذيـة الحيوانـات المزرعيـة فرع تغذيـة الحيـوان، قسم الإنتاج

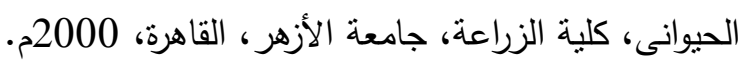


جدول رقم (5) يوضح أهم الأعلاف الخشنة ومواعيد الحصول عليها(2)

\begin{tabular}{|c|c|c|c|c|c|}
\hline موسم الحصول عليه & إنتاج الفدان (كجم) & مادة العلف & موسم الحصول عليه & إنتاج الفدان(كجم) & مادة العلف \\
\hline أكتوير - نوفمبر & 1475 & قثر الأرز & مايو -يونيو -يوليو & 2150 & تبن القــح \\
\hline أكتوير - نوفمبر & 1750 & حطب الذرة & مايو -يونيو -يوليو & 1875 & تبن الثعير \\
\hline أكتوبر - نوفمبر & 2100 & حطب الذرة & مايو -يونيو -يوليو & 800 & تبن البرسيم \\
\hline نوفمبر - ديسمبر & 1425 & حطب القطن & مايو -يونيو & 1050 & تبن العس \\
\hline مايو -يونيو & 1275 & تبن الفول & مايو -يونيو & 825 & تبن الحلبة \\
\hline مايو -يونيو & 1150 & تبن الترمس & مايو -يونيو -يوليو & 900 & تبن الحمص \\
\hline
\end{tabular}

يراعى عند التغذية على الأتبان ألا تستعمل كغذاء أساسى؛ حيث يؤدي ذلك إلى صعوبة موازنة العليقة حيث تنخفض نسبة البروتين

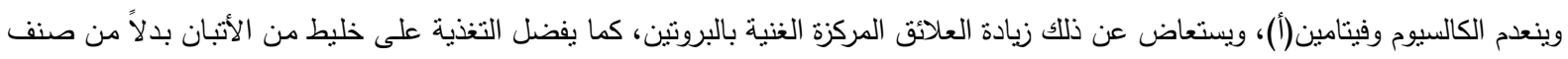

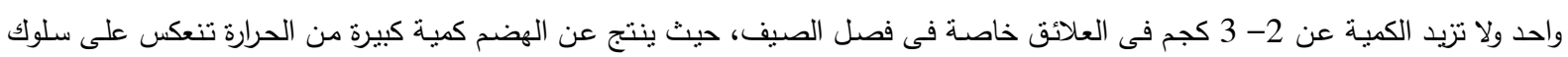

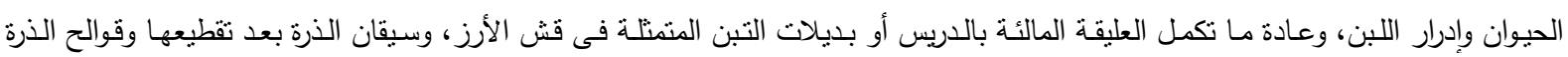

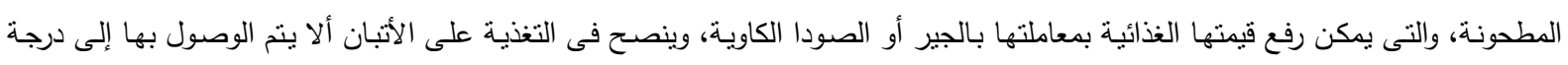

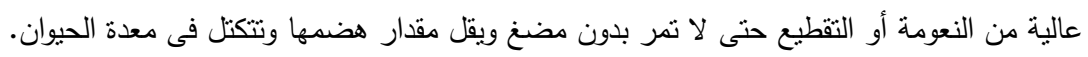

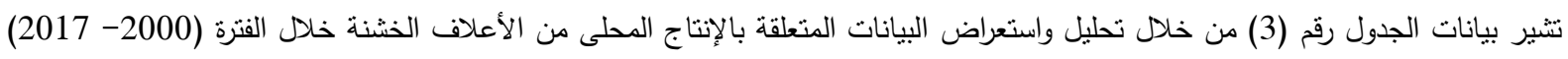

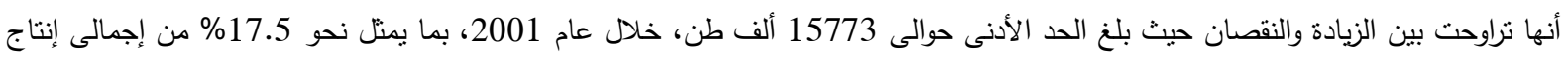

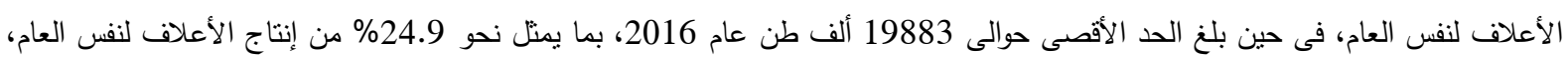

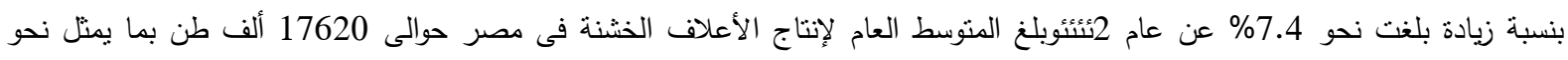

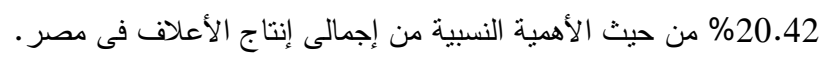

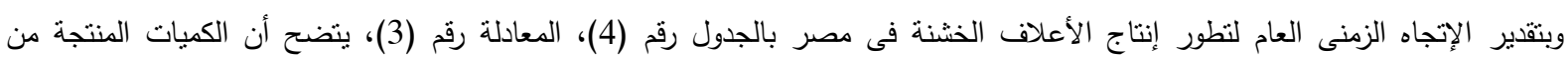

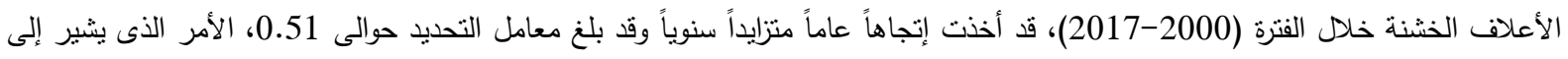

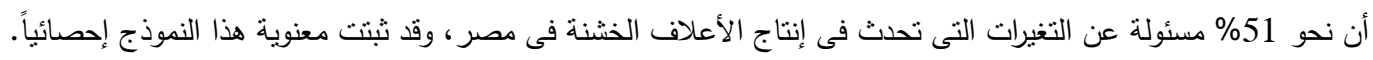

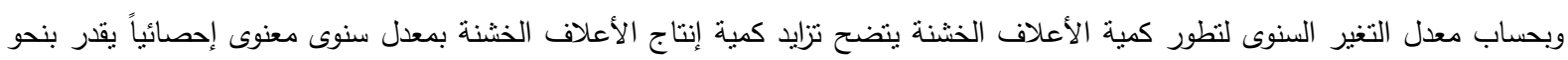
0,8\% من متوسط كمية الأعلاف الخشنة الذى قدر بنحو 17620 ألف طن وذلك خلاف الفنترة (2000-2017).

تندرج المواد المركزة تحت تصنيف الأعلاف ذات القيمة الغذائية العالية قليلة الألياف بالإضافة إلى قيمتها الهضمية المرتفعة، ولذلك كان

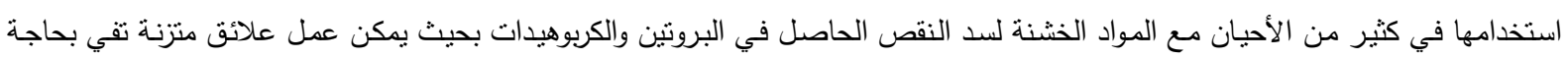

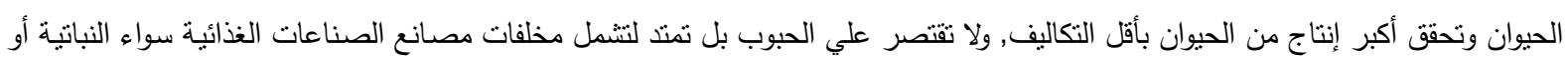

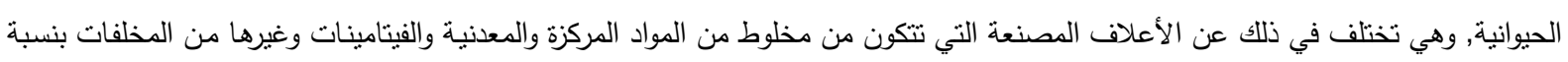
مختلفة تتواءم مع نوع الحيوان وعمره وطبيعة عمله والظروف الجوية، بحيث تمده باحتياجاته من العليقة الحافظة والإنتاجية.

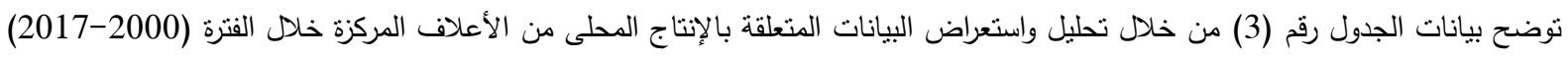

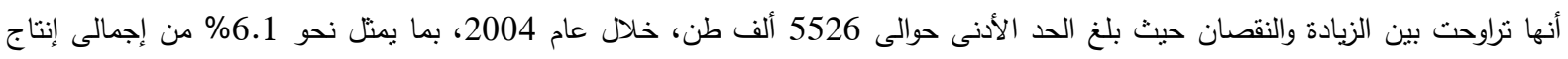

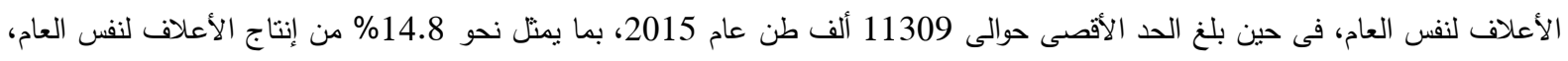

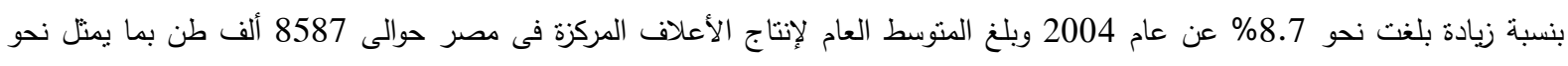

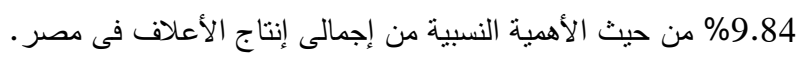

(2) فوزى محمد أحمد عمر أبو دنيا (دكتور): (تسمين الحيوانات المزرعية)، وزارة الزر اعة، الإدارة العامة للثقافة الزر اعية، نشرة رقم (17) لسنة 2002. 
وبتقدير الإتجاه الزمنى العام لتطور إنتاج الأعلاف المركزة فى مصر بالجدول رقم (4)، المعادلة رقم (4)، يتضح أن الكميات المنتجة من

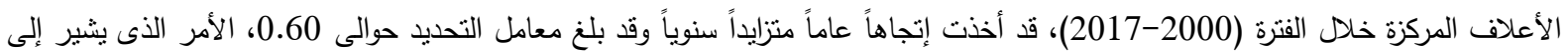

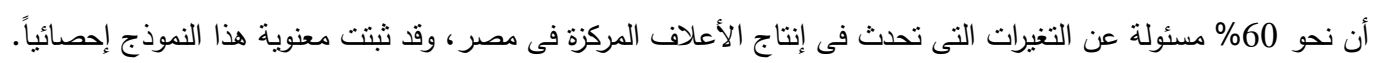

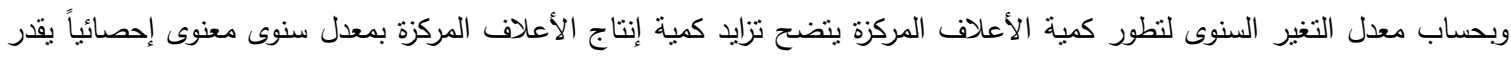
بنحو 2,5\% من متوسط كمية الأعلاف المركزة الذى قدر بنحو 8587 ألف طن وذلك خلال الفنترة (2000-2017).

أنواع العلائق والكمية المستخدمة فى تسمين ماشية اللحوم الحمراء

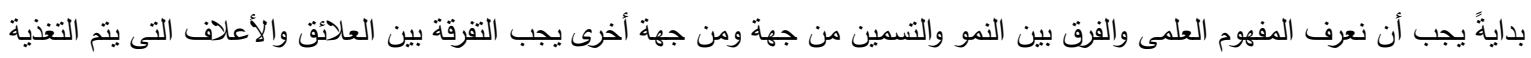
عليها: (3): النمو: هو الزيادة فى العضلات والهيكل العظمى ويشمل الوزن والحجم التسمين: هو دفع الحيوان لزيادة وزنه وحجمه بمعدل أكبر من المعدل العادى وبأقصى حد بسمح به التهي التركيب الوراثى عن طريق التغذية الجيدة. كما يختلف تسمين حسب أنواع التسمين سواء أبقار وجاموس وحسب مدة التسمين سواء تسمين بطئ، أو تسمين سريع، كذلك تسمين الحيوانات تامة النمو.

أولاً: التسمين على مواد العلائق المركزة:

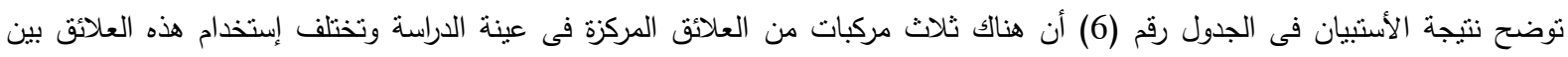

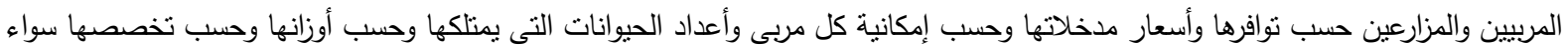
فى إنتاج اللحوم الحمراء أو إنتاج الألبان (4).

أ- تركيب الأعلاف المركزة 14\%:

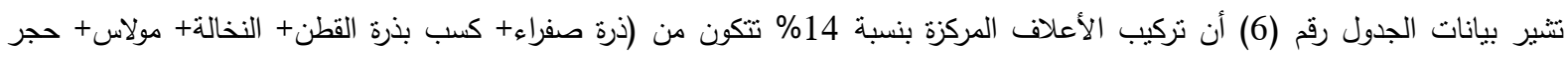

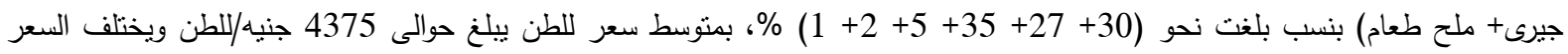
حسب نتوافر المركبات وأسعار النقل أو مصادر الثراء.

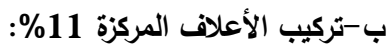

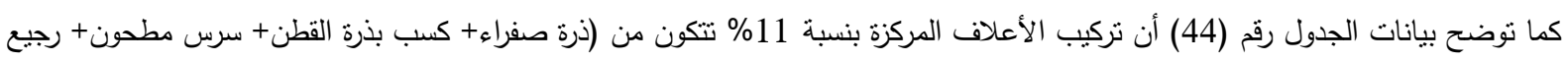

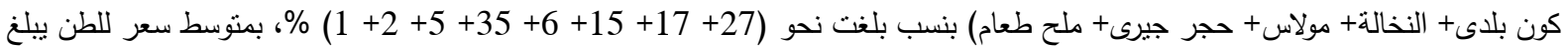
حوالى 3438 جنيه/للطن ويختلف السعر حسب توافز المركبات وأسعار النقل أو مصادر الثراء، وكذلك نسبة التركيز.

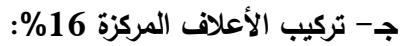

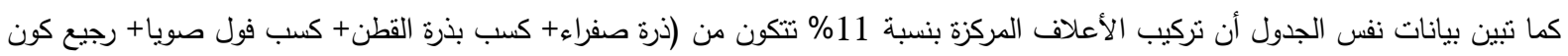

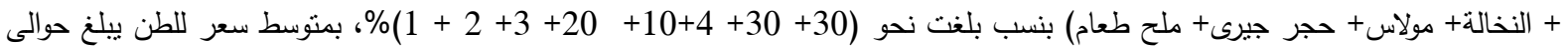
5000 جنيه/للطن ويختلف السعر حسب توافر المركبات وأسعار النقل أو مصادر الثراء، وكذلك نسبة التركيز.

(3) وزارة الزراعة واستصلاح الأراضى، (تسمين الحيوانات المزرعية)، الإدارة العامة للتقافة الزراعية، نشرة رقم 17 لسنة 
الجدول رقم (6) أنواع العلائق المركزة والكمية المستخدمة فى تسمين ماشية اللحوم الحمراء عند المربين .

\begin{tabular}{|c|c|c|c|c|c|c|c|c|}
\hline سعر الطن & $\%$ & تركيب & سعر الطن & $\%$ & تركيب & سعر الطن & $\%$ & تركيب 14\% \\
\hline 4050 & 30 & ذرة صفراء & 4050 & 27 & ذرة صفراء & 4050 & 30 & ذرة صفراء \\
\hline 4600 & 30 & كسب بذرة & 4600 & 17 & كسب بذرة & 4600 & 27 & كسب بذرة قطن \\
\hline 6120 & 4 & كسب فول & 2000 & 15 & مطدون & 3585 & 35 & النخالة \\
\hline 3000 & 10 & رجيع كون & 3000 & 6 & بلديع كون & 1900 & 5 & مولاس \\
\hline 3585 & 20 & النخالة & 3585 & 27 & النخالة & 250 & 2 & حجر جيرى \\
\hline 1900 & 3 & مولاس & 1900 & 5 & مولاس & 500 & 1 & ملح طعام \\
\hline 250 & 2 & حجر جيرى & 250 & 2 & حجر جيرى & - & - & - \\
\hline 500 & 1 & ملح طعام & 500 & 1 & ملح طعام & - & - & - \\
\hline 5000 & 100 & الجملة & 3438 & 100 & الجملة & 4375 & 100 & الجملة \\
\hline
\end{tabular}

من خلال ماسبق يتضح أن تركيز الأعلاف يختلف حسب نسبة البروتين فى المركب، كما يتضح أن كل 1\% من البروتين فى مركبات الأعلاف السابقة تعادل فى التكلفة حوالى 312.5 جنيه. كما يتضح من خلال إستمارة الإستبيان ضرورة إضافة كيلو بيرمكس (مخلوط أملاح+ فيتامينات) حتى لاتتأثز الحيوانات بالحرارة.

ثانياً: التسمين على مواد الأعلاف الخضراء: يختلف التغذية على الأعلاف الخضراء حيث إمكانيات كل مربى وحسب السعر وكذللك حسب توفر الأعلاف المركزة لأنه لايمكن تغذية حيوان التسمين على العلف الأخضر فقط ولكن يتم بجانب الأعلاف المركزة وحسب وزن الحيوان. فمن خلال الجدول رقم (7) الذى يوضح معدل التغذية اليومى على البرسيم والذى يبلغ حوالى 3 كجم/ يومى لحيوان التشمين بالإضافة إلى حوالى الى التي

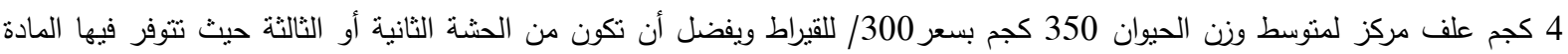

كما تثير بيانات نفس الجدل أنه فى حالة استبدال البرسيم بالاراوة الخضراء فى حالة عدم توفره يتم التغذية على الدراوة الخضراء بمعدل ييلغ حوالى 4 كجم/ يومى للحيوان بسعر ييلغ حوالى 275 للقيراط، بالإضافة إلى مقررات العلف المركز حسب نسبة التئ البروتين.

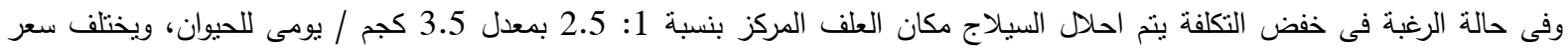
السيلاج باختلاف إذا ماتم كمره بكيزان الذرة أو من غيرها. 


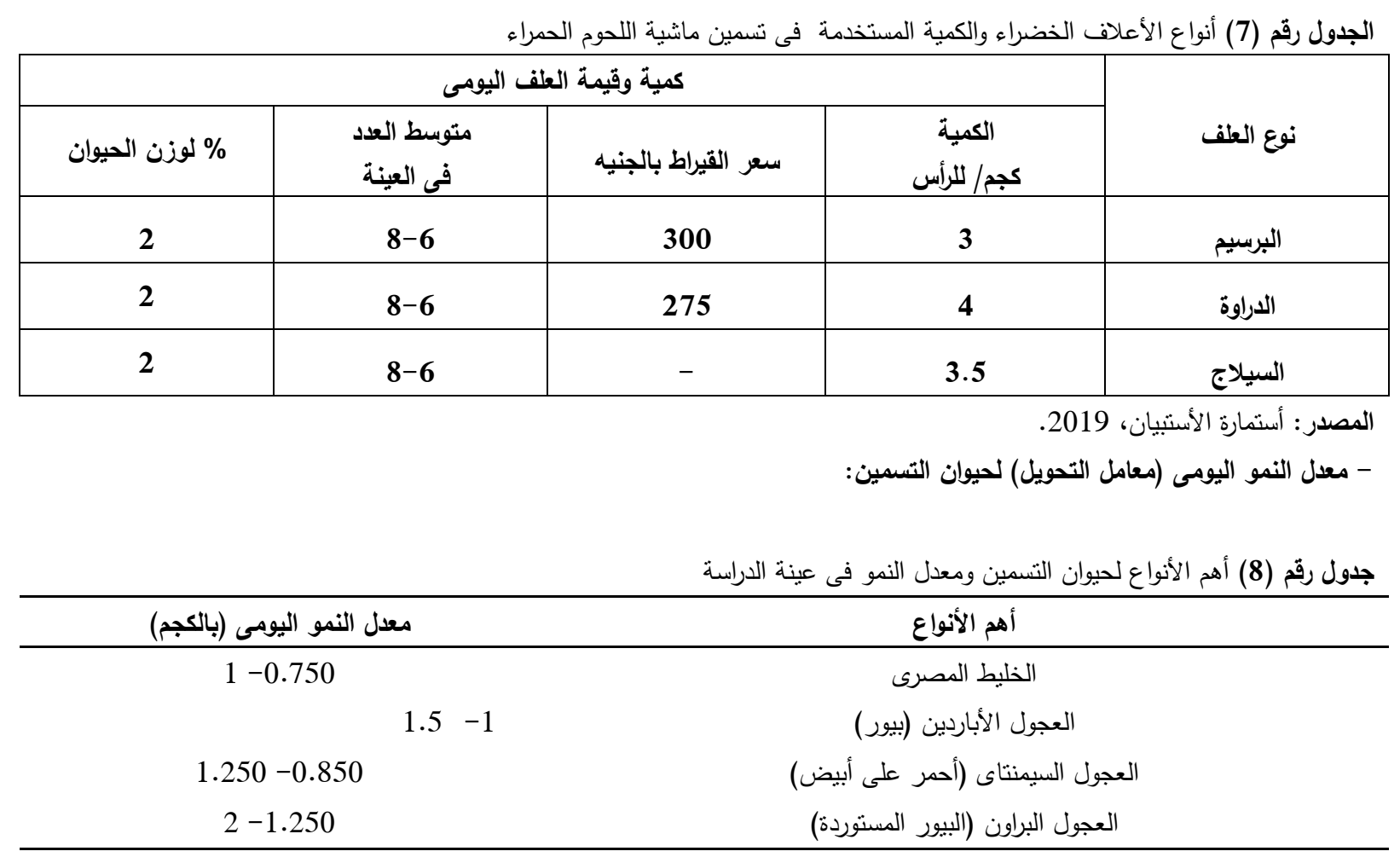

يتم تغذية العجول المستوردة على علف 16\% بروتين للتماشى مع معدل نموها بالإضافة إلى حوالى 6 كجم قش أرز كمادة مالئة، ويتم

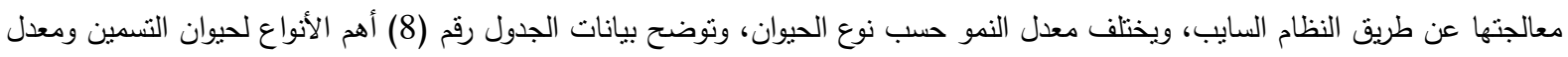
النمو لكل منها، من خلال عينة الدراسة: المصدر : إستمارة الأستيان ، 2019.

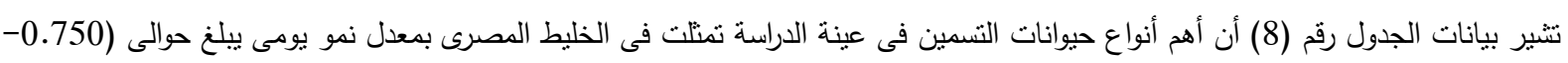

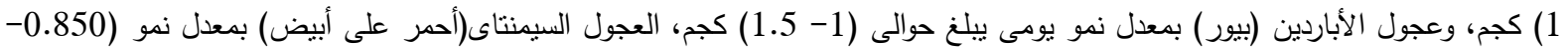

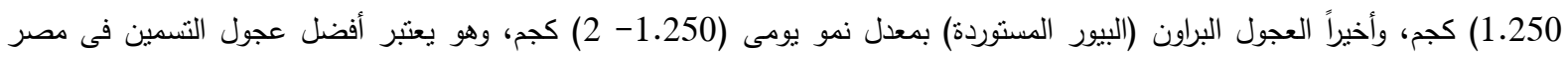

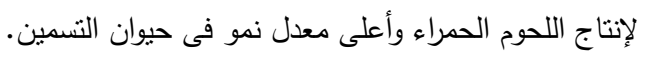

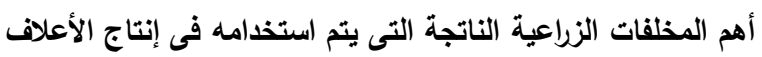

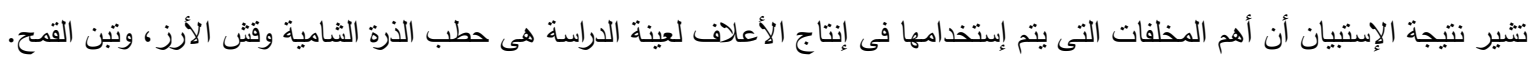

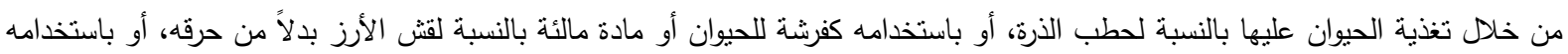
لتغذية الحيوان بالنسبة لتبن القمح لتعويض العلف المركز سواء لإرتفاع سعره، أو لعدم توفره(5).

4- أهم المخلفات الزراعية النى يتم تدويرها فى عينة الدراسة

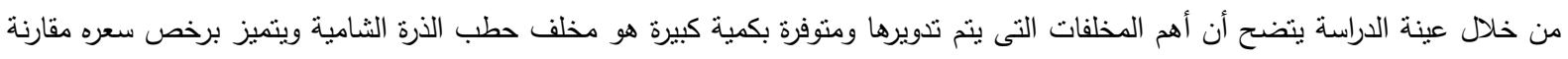
بالعلف المركز حيث يمكن استبداله بالعلف المركز وذلك بنسبة 1: 2.5 وذللك للتظلب على مشكلة إرتفاع أسعار العلف المركز . 5- 5ريقة تدوير حطب الذرة الثامية: يعتبر أهم وأفضل طريقة لتدوير حطب الذرة هى الذرة السيلاج بكيزان الذرة عن طريق الكمر لإنتاج بروتين يعادل 7\%ة، ويتم دراسه ثم يُكبس

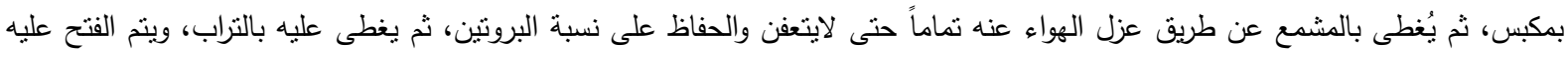

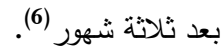


أهم المعوقات والمشاكل التى تواجه المزارع فى الإستفادة من المخلفات الزراعية

1 - 2- عدم وجود أماكن لتجميع المخلفات الزراعية.

2- - عدم وجود مصانع لتنوير المخلفات الزراعية.

3- - عدم توفر الآلات اللازمة للتنوير.

4- - عدم وجود برامج تدرييية وإعلامية لتوعية المزارعين.

5- - عدم توفر مرشدين زراعيين متخصصين.

6- - - إرتفاع تكاليف النقل والتجميع.

7- - - إرتفاع أسعار الخامات ومدخلات الإنتاج.

ثائًا :الآثار الاقتصادية لاستخدام السيلاج وقش الأرز المعامل فى عليقة حيوانات التسمين

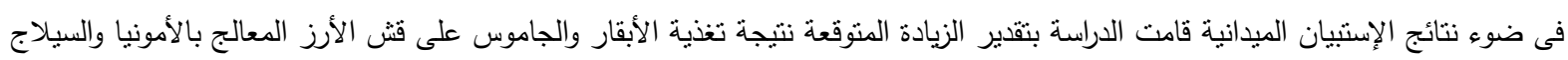
وتقدير قيمة الوفر فى التكاليف وكمية العليقة المستخدمة فى عينة الدراسة.

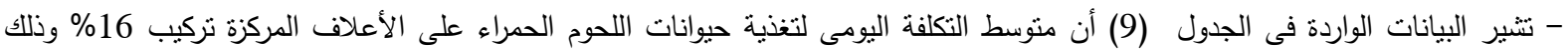
حسب النسبة الداخلة فى التغذية اليومية حوالى 5 جنيد/يوم بنسبة تبلغ نحو 104\% من منوسط تكلفة العلائق المركزة وغير المركزة فى عينة الدراسة، كما تثير بيانات نفس الجدول أن التغذية على الأعلاف المركزة تركيب 14\%، 11 18\% وذلك حسب النسبة الداخلة في التغذية اليومية

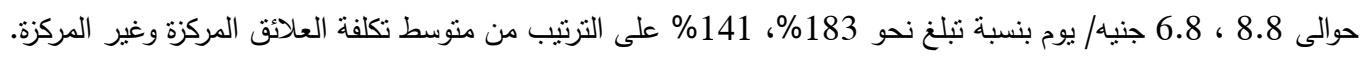

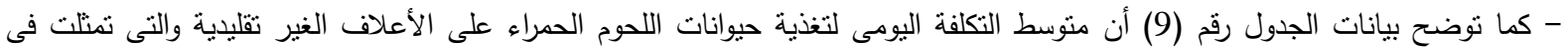

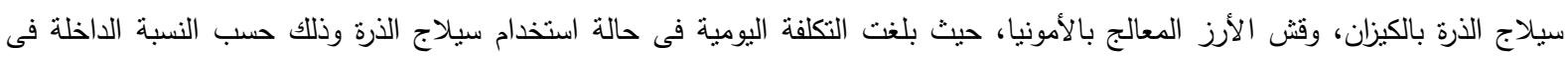
التغذية اليومية حوالى 1.9 جنيه/يوم بنسبة تبلغ نحو 39\% من متوسط تكلفة العلائق المركزة وغير المركزة في عينة الدراسة.

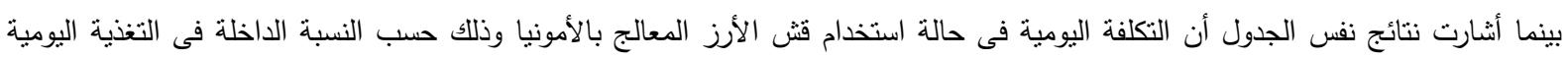

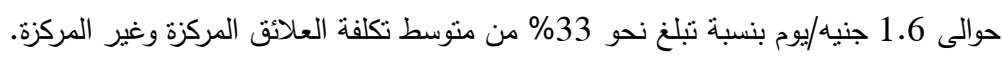

الجدول رقم (9) تكاليف العلائق المركزة والغير التقليدية المستخدمة فى تسمين الماشية (الطن/ بالجنيه)

\begin{tabular}{|c|c|c|c|c|c|}
\hline$\%$ & الليومية & معدل التفذية اليومى & متوسط سعر & تكلفة الطن & 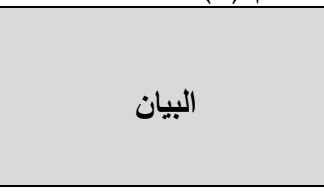 \\
\hline 104 & 5 & 1 كجم/يوم & 5 & 5000 & تركيب 16\% \\
\hline 183 & 8.8 & 2 كجم/يوم & 4.4 & 4375 & تركيب 14\% \\
\hline 141 & 6.8 & 2 كجم/يوم & 3.4 & 3438 & تركيب 11\% \\
\hline 39 & 1.9 & 3.5 & 0.54 & 538 & سيلاج الذرة الثامية \\
\hline 33 & 1.6 & 3.5 & 0.45 & 445 & قش الأرز المعالج بالأمونيا \\
\hline- & 4.82 & الجملة & 4375 & 100 & المتوسط \\
\hline
\end{tabular}

المصدر : إستمارة الإستنيان 2019.

ومن خلال الننائج السابقة فإنه يمكن تقدير الوفر المتوقع لنكاليف إنتاج اللحوم الحمراء فيما لو تم تعميم العليقة التى تحتوى على السيلاج أو قش الأرز المعامل بالأمونيا، وذلك بناء على ما توصلت إليه نتائج الدراسة الميدانية.

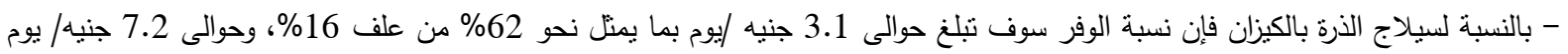

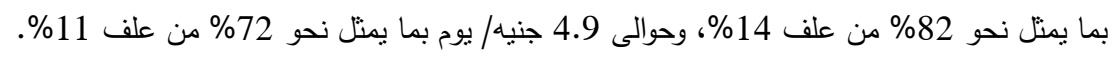

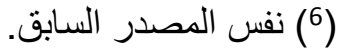




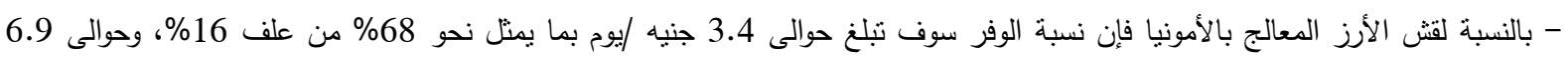

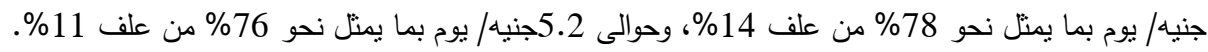

الملخص والتوصيات

تعد مثكلة نقص البروتين الحيواني من أهم المشكلات التى تعترض تحسين المستوى الغذائي فى الدول النامية، وذلك للزيادة السكانية بمعدلات تفوق كثيراً إنتاج السلع الغذائية بصفة عامة والبروتين الحيوانى بصفه خاصة. تتتلل مثكلة البحث في عجز الطاقة الإتناجية من الموارد العلفية للحيوانات المزرعية فى الزراعة المصرية عن تغطية الإحتياجات الحيوانية لتلكي

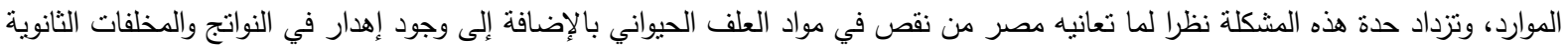

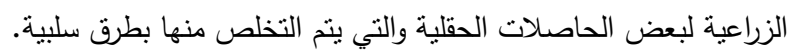
ويهدف البحث إلى دراسة الوضع الإنتاجي الراهن لماثية التسمين في جمهورية مصر العربية بصفة عامة وكنلك دراسة الوضع الإنتاجى

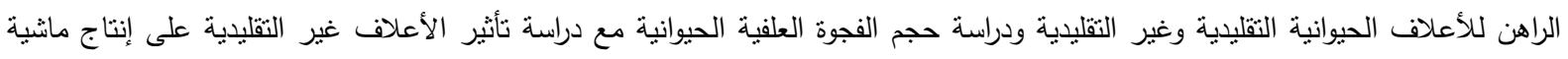
التسمين. فيما يتعلق بدراسة الوضع الإنتاجى للحوم الحمراء فى مصر خلال منوسط الفترة (2000-2017) يتضح أن الحد الأدنى لإنتاج اللحوم فى

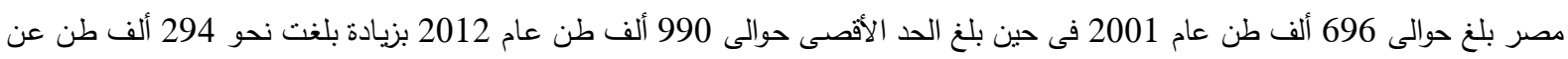

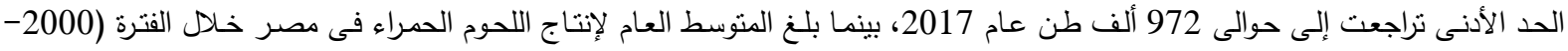
2017) حوالى 904 ألف طن سنوياً. بدراسة الإنتاج المحلى من الأعلاف المركزة خلال الفترة (2000-2017) اتضح أنها تراوحت بين الزيادة والنقصان حيث بلغ الدد الأدنى حوالى

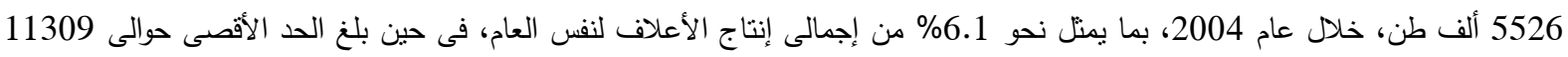

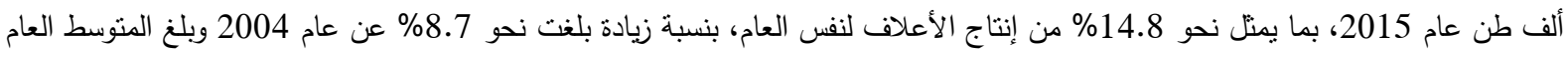

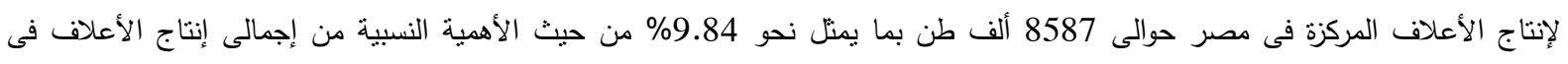
بالنسبة وبدراسة أهم المخلفات الزراعية الناتجة النى ينم استخدامه فى إنتاج الأعلاف أثنارت نتيجة الإستيان أن أهم المخلفات التى ينتم

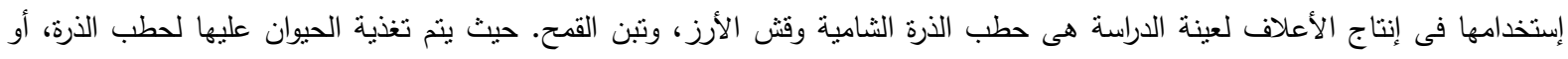

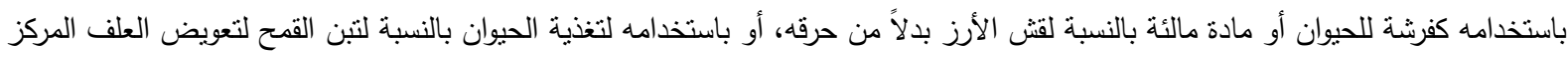
سواء لإرتفاع سعره، أو لعدم توفره.

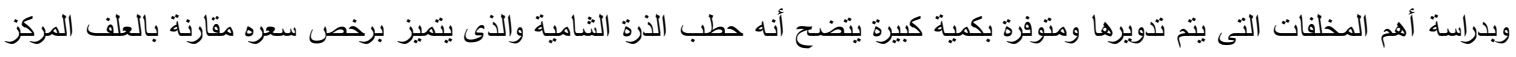

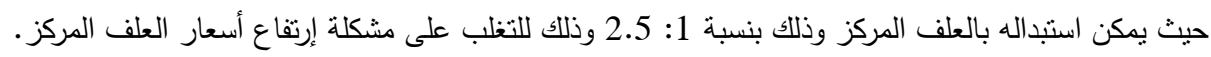

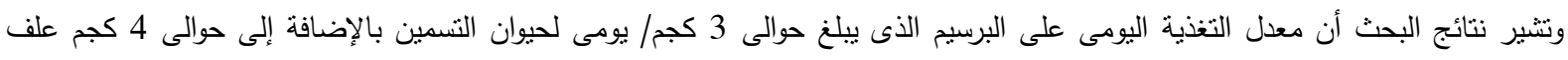

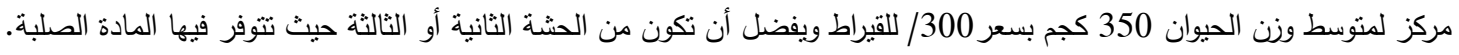

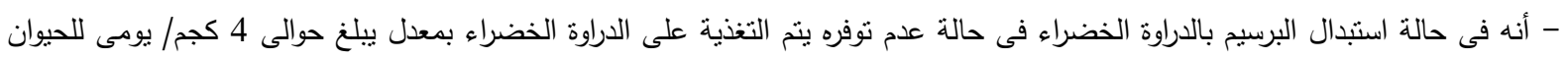

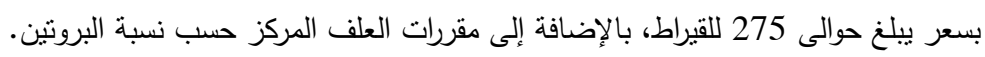

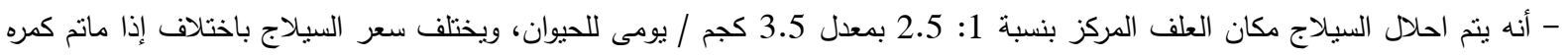
بكيزان الذرة أو من غيرها. - أن تركيز الأعلاف يختلف حسب نسبة البروتين فى المركب، كما يتضح أن كل 1\% من البروتين فى مركبات الأعلاف السابقة تعادل فى التكلفة حوالى 312.5 جنيه ويوصى البحث بالتوصيات التالية: 1- ضرورة توفير مرشدين زراعيين وبرامج تدريبية لتنريب العاملين فى هذه الوحدات على إنتاج العلائق غير التقليدية. 2- - ضرورة توفير الآلات الخاصة بكبس وتقطيع وفرم المخلفات الزراعية لخفض تكلفة التدوير . 3- العمل على توفير القروض اللازمة لعملية الإنتاج بأسعار فائدة منخفضة. 


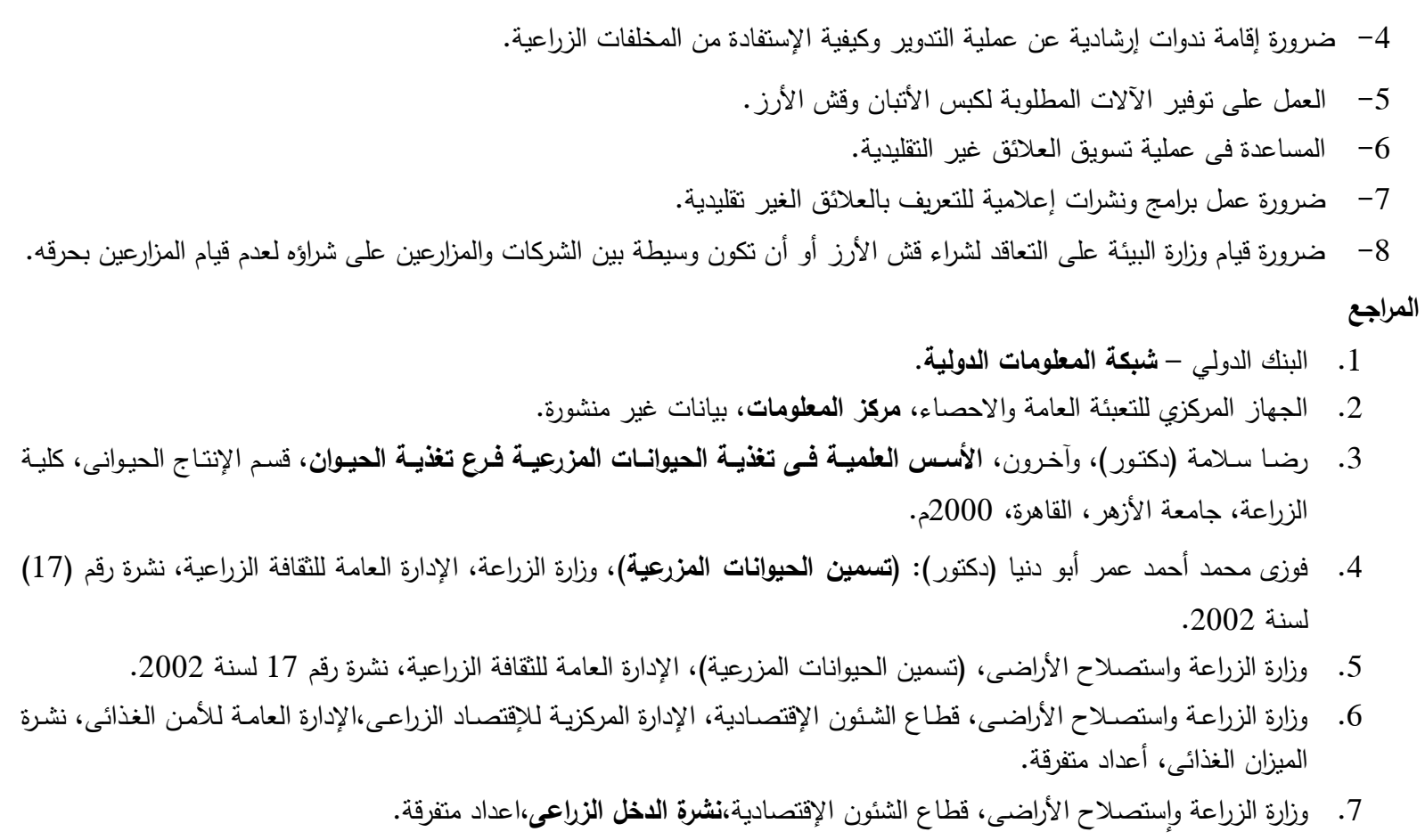




\title{
The Effect of Unconventional Diets on the Production of Red Meat in Egypt
}

\author{
Mohamed Kamal Eldin Hassan \\ Agricultural Economics Research Institute, Agric. Res. Center, Giza, Egypt \\ Corresponding author: mm_elsheikh2005@yahoo.com
}

The problem of animal protein deficiency is one of the most important problems facing the improvement of the food level in developing countries. The problem of research is the inability of the productive capacity of the feed resources of farm animals in Egyptian agriculture to cover the animal needs of these resources, and this problem is exacerbated due to Egypt's lack of animal feed materials in addition to the waste in agricultural products and by-products of some field crops. Get rid of them in negative ways. The research aims to study the current production status of fattening livestock in the Arab Republic of Egypt in general as well as the current production situation of traditional and non-traditional animal feed and study the size of the animal feed gap with the study of the impact of non-traditional feed on the production of fattening livestock. With regard to the study of the production situation of red meat in Egypt during the average period (2000-2017) it is clear that the minimum production of meat in Egypt reached about 696 thousand tons in 2001, while the maximum reached about 990 thousand tons in 2012, an increase of about 294 thousand tons The minimum level dropped to about 972 thousand tons in 2017, while the average annual production of red meat in Egypt during the period (20002017) about 904 thousand tons annually. The study of the local production of concentrated feed during the period (2000-2017) showed that it ranged between increase and decrease as the minimum amount reached about 5526 thousand tons during 2004, which represents about $6.1 \%$ of the total feed production for the same year, while the maximum amount was about 11309 thousand tons in 2015, representing about $14.8 \%$ of the production of feed for the same year, an increase of about $8.7 \%$ over 2004 . The overall average production of concentrated feed in Egypt about 8587 thousand tons, representing about $9.84 \%$ in terms of the relative importance of the total production Feed in Egypt.

The results of the questionnaire indicated that the most important wastes that are used in the production of fodder for the study sample are maize firewood, rice straw, and wheat straw. Where the animal is fed to it for corn firewood, or used as an animal bed or filler for rice straw instead of burned, or used to feed the animal for wheat straw to make up for concentrated feed, either because of the high price, or lack of availability.

The study of the most important waste that is recycled and available in a large quantity it is clear that maize firewood, which is characterized by its cheaper price compared to concentrated feed where it can be replaced with concentrated feed by $1: 2.5$ to overcome the problem of high prices of concentrated feed.

The results indicate that the daily feed rate on alfalfa, which is about $3 \mathrm{~kg} /$ day for fattening animals, in addition to about $4 \mathrm{~kg}$ concentrated feed for the average weight of the animal $350 \mathrm{~kg}$ at a price of $300 /$ carat, preferably from the second or third filler where the solid material is available.

- In the case of alfalfa substitution with green draining in case it is not available, feeding on the green draining at a rate of about $4 \mathrm{~kg} /$ day for the animal at a price of about 275 carats, in addition to the decisions of fodder concentrated according to the proportion of protein.

- That the silage is replaced by concentrated feed at a rate of $1: 2.5$ at a rate of $3.5 \mathrm{~kg} /$ day for the animal, and the price of silage varies depending on whether it is Bmrh corn corn or other.

- The feed concentration varies according to the percentage of protein in the compound

\section{The following recommendations are recommended:}

1- The need to provide agricultural extension workers and training programs to train workers in these units in the production of non-traditional feeds.

2 - the need to provide machines for pressing, cutting and chopping agricultural waste to reduce the cost of recycling.

3- Providing the necessary loans for the production process at low interest rates.

4 - the need to hold seminars on the process of recycling and how to take advantage of agricultural waste.

5- Providing the required machines for pressing straws and rice straw.

6 - help in the process of marketing non-traditional feeds.

7 - the need to make programs and information leaflets to identify non-traditional relations.

8 - The need for the Ministry of Environment to contract for the purchase of rice straw or to be intermediary between companies and farmers to buy it because the farmers do not burn it. 